\title{
Considerações acerca da distribuição de terras na região da Baía da Babitonga
}

\author{
Considerations about land distribution \\ in the Babitonga Bay area, Santa Catarina, Brazil
}

Eleide Abril Gordon Findlay ${ }^{1}$

\begin{abstract}
Resumo: A análise do processo histórico da ocupação territorial do nordeste de Santa Catarina, durante os períodos colonial e imperial, com base em fontes documentais, indica que o povoamento ocorreu através da concessão de sesmarias, distribuição de terras devolutas promovida pelas autoridades governamentais e a implantação de colônias estrangeiras. Os dispositivos legais contribuíram de maneira significativa para a constituição de uma estrutura fundiária baseada na pequena propriedade.
\end{abstract}

Palavras-chave: ocupação territorial, distribuição de terras, Baía da Babitonga, Santa Catarina.

\begin{abstract}
The analysis of the historical process of the territorial occupation of the northeast of Santa Catarina, during the colonial and imperial periods, based on government documents, indicates that the settlement took place through the concession of allotments, distribution of returned lands promoted by the government authorities and the introduction of foreign colonies. The legal provisions have contributed significantly to the establishment of a land structure based on small property.
\end{abstract}

Keywords: Territorial occupation, distribution of land, Babitonga Bay, Santa Catarina (Brazil).

\section{Introdução}

A ocupação territorial em Santa Catarina, mais especificamente do litoral nordeste, tem se constituído em objeto de minhas pesquisas ao longo dos últimos anos e nesse período diversas especificidades do povoamento do território da baía da Babitonga ${ }^{2}$ têm demonstrado a necessidade de um

\footnotetext{
${ }^{1}$ Mestre em Educação; docente da Universidade Regional de Joinville - UNIVILLE, Santa Catarina. E-mail: efindlay@terra.com.br. Pesquisa financiada pelo FAP/UNIVILLE.

${ }^{2}$ A Baía da Babitonga tem uma extensão de $23 \mathrm{~km}$. Com 24 ilhas ao todo, é o maior estuário do Estado de Santa Catarina. Em língua indígena significa morcego.
} 
maior aprofundamento e detalhamento do tema. ${ }^{3}$

No processo histórico da construção da sociedade catarinense, o ordenamento jurídico desempenhou papel significativo na constituição da história fundiária do Estado. Evidentemente que a legislação não pode ser descolada dos múltiplos elementos que estruturam a realidade social. Maria Yedda Linhares afirma que o estudo da história agrária na realidade contempla, além das normas jurídicas, a história econômica e social de qualquer localidade, e que por este motivo deve:

[...] contemplar os elementos que se associam a um fim que seja possível explicação inteligível do processo na agricultura, colocando-se no tocante àqueles fatores questões prévias: o sistema socioeconômico em questão, as condições de acesso à terra, as normas jurídicas que regem a propriedade, o meio geográfico e as condições de uso da terra, o perfil demográfico, o universo profissional, as hierarquias sociais. ${ }^{4}$

Nesta perspectiva, os estudos mais recentes desenvolvidos na área da História Social na Agricultura colocaram no centro do debate regiões e agentes sociais até então esquecidos ou desprezados pela produção acadêmica. E principalmente demonstraram a necessidade de se entender a diversidade da inserção social do homem livre na sociedade escravista e sua importância na construção do mercado interno, na experimentação e cultivo de novos produtos, e na criação de estratégias de sobrevivência. ${ }^{5}$

\footnotetext{
${ }^{3}$ FINDLAY, Eleide A. G. A ocupação territorial e a política agrária na província de Santa Catarina no século XIX. In: Anais do XXV Simpósio Nacional de História. Fortaleza: ANPUH, 2009. p.1-10; FINDLAY, Eleide A.G.. As disputas de terras no Termo de São Francisco Xavier de Joinville. In: Anais do XXVI Simpósio Nacional de História ANPUH 50 Anos. São Paulo, 2011. Disponível em: <http://www.snh2011.anpuh.org/resources/anais/14/1307386573_ARQUIVO_Asdisputasdet errasnoTermodeSaoFranciscoXavierdeJoinville(1).pdf>. Acesso em: 18 out.2011.

${ }^{4}$ LINHARES, Maria Yedda. História Agrária. In: CARDOSO, Ciro Flamarion, VAINFAS, Ronaldo (orgs). Domínios da História: ensaios de teoria e metodologia. 5.ed. Rio de Janeiro: Campus, 1997. p.170

${ }^{5}$ Ver MATTOS, Hebe. Ao sul da História: lavradores pobres na crise do trabalho escravo. 2. ed. rev. ampl.. Rio de Janeiro: FGV, Faperj, 2009; MOTTA, Márcia Menendes. Nas fronteiras do poder: conflito e direito à terra no Brasil do século XIX. Rio de Janeiro: Vício de Leitura/APERJ, 1998; MOTTA, Márcia, SECRETO, María Verónica (orgs). O Direito às Avessas: por uma história social da propriedade. Guarapuava: Unicentro, 2011; Niterói, EDUFF, 2011; MACHADO, Paulo Pinheiro. Lideranças do Contestado. Campinas: UNICAMP, 2004.
} 
A percepção dos governantes provinciais, exposta nos relatórios e discursos à Assembleia Legislativa, acerca do acesso à terra pelos homens brancos pobres que habitavam a região, é significativa para a compreensão do processo histórico de povoamento da baía da Babitonga. ${ }^{6}$ O conjunto dos dados obtidos nas pesquisas de campo efetuadas em arquivos públicos reafirma a convicção de que o processo de ocupação territorial da região esteve submetido às mesmas diretrizes nacionais. Ou seja, concessão de sesmarias, doação de terras devolutas e a constituição de colônias agrícolas estrangeiras. A análise dos momentos mais significativos desse processo constitui o propósito do artigo.

\section{A concessão de sesmarias}

$\mathrm{O}$ processo de povoamento do litoral catarinense principiou com a vinda dos bandeirantes paulistas da Capitania de São Vicente ${ }^{7}$ (vicentinos, santistas, piratininguenses, moradores da capitania de São Paulo) para a região do núcleo de São Francisco do Sul, com o objetivo de capturar indígenas, buscar produtos e metais.

A presença desses grupos colaborou para que, através do Alvará Régio de 1656, surgisse a Freguesia de Nossa Senhora das Graças do Rio de São Francisco, subordinada à Vila de Paranaguá. O povoamento do litoral catarinense pelos vicentistas, estimulados pela Coroa Portuguesa diante da necessidade de proteção do território frente às constantes expedições espanholas, fez surgir a Vila de Nossa Senhora do Desterro (1678) e a Vila de Santo Antônio dos Anjos da Laguna (1683). A forma de acesso à terra pelos povoadores do núcleo de São Francisco do Sul foi análoga à que caracterizou o período colonial brasileiro: a concessão de sesmaria aos indicados por sesmeiros ou por requerimento de um lote de terra diretamente à Coroa Portuguesa. ${ }^{8}$

\footnotetext{
${ }^{6} \mathrm{Na}$ área da baia da Babitonga encontram-se os municípios de São Francisco do Sul, Joinville e Araquari.

${ }^{7}$ Os bandeirantes eram ricos homens de negócios, descendentes de portugueses, mamelucos (português com índio) ou portugueses natos, que viviam notadamente em Cananéia, Santos e São Vicente. Ver: FARIAS Vilson Francisco de. De Portugal ao Sul do Brasil - 500 anos: História - Cultura- Turismo. Florianópolis: Ed.do autor, 2001. p.74.

8 SILVA, Fernando João da. A divisão político-administrativa do Estado de Santa Catarina: do passado ao presente. Florianópolis, 2008. 255 f. Dissertação (Mestrado Profissional em Planejamento Territorial e Desenvolvimento Socioambiental). UDESC.
} 
Inicialmente deve-se destacar que a ocupação do litoral nordeste catarinense, como da própria Santa Catarina, se iniciou sob a égide da legislação de sesmarias de 1375, e principalmente do Alvará de 5 de outubro de 1795, sobre a regulamentação das doações de sesmarias. Como alerta Márcia Motta, ${ }^{9}$ apesar do pouco interesse da produção historiográfica em relação a esse documento legal, em seus dispositivos encontram-se muitas das intenções da Coroa em relação à normatização do acesso à terra na colônia brasileira. Para a autora, a noção de igualdade na concessão de terras está expressa no item VI: "mais que meia légua em quadra, a fim de que haja entre todos os ditos moradores a igualdade que merece". ${ }^{10} \mathrm{E}$ precisamente no item VII deste instrumento legal pode residir a explicação para a dimensão das terras requeridas e doadas na região durante o período colonial.

[...] se não facultarão daqui em diante mais de meia légua de frente, dando-se a outra meia, que até agora se lhes permitia, no fundo das mesmas terras, a fim de que pelo meio desta providência resulte o maior número de habitantes, que povoem estes desertos caminhos; o maior argumento da cultura, em que tanto interessa o público; o maior número de sesmeiros, que façam mais vantajosos os efeitos, e fins da mesma cultura. ${ }^{11}$

No Brasil, o estatuto das sesmarias toma formato distinto do da Metrópole. O Alvará de 5 de outubro de 1795 determinou que o direito à concessão de sesmaria pertenceria aos governadores e capitães-generais. Não podia obter concessão quem já possuísse uma anterior e aos estrangeiros era vedada a concessão, o que se alterou em Decreto de 25 de novembro de 1809. A extensão não podia exceder a três léguas. Em algumas capitanias era fixada em uma légua ou até mesmo em meia légua.

A região sul do Brasil tem sido identificada como aquela em que a doação de terras através do sistema de sesmarias permitiu a formação de pequenas e médias propriedades. Como afirma Nelson Nozoe, as concessões de sesmarias com uma extensão muito grande eram exceções, e normalmente, principalmente no sul, não excediam de três léguas de

\footnotetext{
${ }^{9}$ MOTTA, Márcia Maria Menendes. Direito à terra no Brasil: a gestação do conflito,17951824.São Paulo: Alameda, 2009.

${ }^{10}$ Ibidem, p.87.

${ }^{11}$ Idem.
} 
extensão, onde predominavam "[...] lavradores que se estabeleciam nos lotes doados onde, com o concurso de seus escravos, dedicavam-se à lide agrícola". ${ }^{2}$ Para Serra, "[...] no Paraná e em Santa Catarina, é que se constituiu a maior área contínua de pequenas propriedades rurais no país, baseadas no trabalho familiar, as quais diversificaram muito a produção com as culturas cerealíferas, frutíferas e forrageiras". ${ }^{13}$

De acordo com os dados obtidos em arquivos públicos estaduais e municipal, ${ }^{14}$ na região da baía da Babitonga as terras doadas em sesmaria e também as requeridas mediam no mínimo 70 braças e no máximo 1.500 braças, ${ }^{15}$ com exceção daquelas cujos requerentes já ocupavam a terra desde o século XVIII.

Entre os pedidos de sesmarias constantes no acervo do Arquivo do Estado de São Paulo existe carta de concessão de sesmaria de 1753, onde o requerente José Luiz Marinho informava já estar de posse de mil e quatrocentas braças de terra na paragem do Cubatão de Terra Firme. Podese também observar que o requerente justificava o motivo do pedido: "que necessitava de carta de sesmaria para o poder usufruir nas ordens de Sua Majestade". ${ }^{16}$ Recebeu a concessão em 2 de junho de 1753, com a dimensão solicitada.

Existiam, também, aqueles que requeriam a regularização de lotes ocupados pela família há mais de cinquenta anos, como é o caso do documento, de 1804, dos irmãos Antônio Rodrigues, Francisco Rodrigues, Francisco Rodrigues de Miranda, Maria Alves, Manuel Pereira da Costa, Pedro Martins e Salvador Rodrigues, filhos de José Rodrigues Vidal, moradores do Rio de São Francisco do Sul, todos estabelecidos com suas

\footnotetext{
12 NOZOE, Nelson. Sesmarias e apossamento de Terras no Brasil Colônia. In: Anais eletrônicos do XXXIII Encontro Nacional de Economia, ANPEC, 2005. Disponível em <http://www.anpec.org.br/encontro2005/artigos/A05A024.pdf>. Acesso em: 23 mar. 2009. p.6.

${ }^{13}$ SERRA, Carlos Alberto Teixeira. Considerações acerca da evolução da propriedade da terra rural no Brasil. ALCEU, v.4, n.7, p. 231-248, jul.-dez. 2003. p.241. Disponível em: <http://revistaalceu.com.puc-rio.br/media/alceu-n7-Serra.pdf>. Acesso em: 23 mar. 2009.

14 Arquivo do Estado de São Paulo (AESP), Arquivo do Estado de Santa Catarina (AESC) e Arquivo Histórico de Joinville (AHJ).

${ }^{15}$ Cada braça equivale a 2,20 metros. A légua equivale a 3.000 braças.

${ }^{16}$ Carta de confirmação de Sesmaria a José Luiz Marinho. Arquivo do Estado de São Paulo (AESP). Doc. 1, folha 27.1753.
} 
famílias na região localizada nas cabeceiras do Rio Parati, na localidade denominada Morro do Martinho. ${ }^{17}$

Ao longo do período colonial constam inúmeros pedidos de concessões provenientes de integrantes dos serviços militares e que não se enquadravam no dispositivo legal, que impunha que cada sesmeiro deveria ser capaz de trabalhar nas sesmarias recebidas. No entanto, como destaca Motta, "[...] podemos compreender como as sesmarias tornaram-se um objeto desejado e passível de ser conseguido por distintos estratos sociais." 18 E prossegue a autora: "[...] tal título estava intimamente ligado a um exercício prático, ou seja, em poder se auto-intitular senhor e possuidor de terras, tendo como base uma mercê que lhe conferia um título legitimo". ${ }^{19}$

Para a área do núcleo de São Francisco foram localizadas as seguintes concessões de sesmarias militares, entre 1770 e 1822: ao capitão Francisco José Pereira Coutinho (duas léguas em quadra), ao tenente de milícias Jose Ferreira de Souza (meia légua em quadra), ao sargento mor Ignácio José Cardoso (uma légua), ao alferes Manoel Ferreira de Souza, (150 braças de frente com 450 de fundos), ao soldado Gabriel José Pereira (200 braças de frente com 420 de fundos), ao tenente de milícias André Borges Pitta (100 braças de frente com 1.000 de fundos), ao alferes Salvador Gomes de Oliveira (200 braças de frente com 1.000 de fundos) e ao tenente de milícias Joaquim José de Castro (160 braças de frente com 254 de fundos). ${ }^{20}$

À importância de ser reconhecido como proprietário de terras legitimado por uma carta de sesmaria unia-se, por vezes, o desejo de atender ao preceito legal. Como ressalta Carlos Frederico Marés: "A lei de sesmaria assumiu integralmente a ideia da propriedade como direito de usar a terra e, mais do que isso, a obrigação de nela lavrar. Por isso, antes de ser uma lei de direitos, é uma lei de obrigações." ${ }^{21}$ Porém, para cumprir a determinação legal, muitas vezes ficaram expostos possíveis embates em relação ao acesso à terra. No requerimento datado de abril de 1823, Faustino Alves da Rosa solicitava à Sua Majestade Imperial que lhe concedesse uma porção de terra, por ser

\footnotetext{
${ }^{17}$ Requerimento de sesmaria por Antonio Rodrigues e irmãos. 1804. Arquivo do Estado de Santa Catarina (AESC). Caixa 1, Pacote 2-P.

${ }^{18}$ MOTTA, Direito à terra no Brasil, op. cit. p.196.

${ }^{19}$ Ibidem, p. 198.

${ }^{20}$ Cartas de sesmaria a integrantes das forças militares (AESC e AHJ).

${ }^{21}$ MARÉS, Carlos Frederico. A função social da terra. Porto Alegre: Sergio Antônio Fabris Editor, 2003. p.31.
} 
[...] morador no Rio de São Francisco na Comarca de Santa Catarina, tendo família numerosa e não tendo terras para cultivar, e que o Alferes Salvador Gomes de Oliveira, homem abastado, rico e um dos mais poderosos do lugar possuía não menos de três Sesmarias no Rio Paraty, uma comprada [?] e duas dadas e todas incultas. ${ }^{22}$

Para tanto, requereu o Suplicante, ao Governo Imperial,

[...] que lhe concedesse por sesmaria alguma porção das mesmas terras, pois que aquelas ditas concessões ao suplicado Salvador Gomes de Oliveira estão ilegais e reprovadas e não menos [ilegível] a sua conservação por estarem devolutas contra as cláusulas que foram dadas àquele sesmeiro. ${ }^{23}$

Assim, seu principal argumento baseava-se no preceito legal, o Alvará de 5 de outubro de 1795 , $\S$ XI, que proibia a concessão de uma data de terras a quem anteriormente já tinha recebido concessão. ${ }^{24}$ No mesmo processo está anexada uma correspondência dirigida aos governantes provinciais, com data de junho de 1822 , em que o requerente questiona uma data de terra obtida pelos alferes Salvador Gomes de Oliveira e, em sua fundamentação, afirma:

Ora, Ilustríssimos Senhores, com o devido respeito, que os males dos povos provêm dos Governantes e da triste administração e da alteração só prestada ao cidadão que mais figura por acidente na multidão social. Vem da desordem, da má distribuição [...] os Secretários do Governo têm em si o dever de observar e ver em seu abecedário de distribuição de Graças em nome do Regente da Nação para com os cidadãos que requerem e informar aos Governantes, se este, e aquele, já obtiveram mercês de campos e não a um mais rico se

\footnotetext{
${ }^{22}$ Requerimento de terras por Faustino Alves da Rosa. 1823. Arquivo Histórico de Joinville (AHJ). CMC, 33.0.01.01.31, caixa 1.

${ }^{23}$ Ibidem.

${ }^{24}$ LIMA, Ruy Cirne. Pequena história territorial do Brasil: sesmarias e terras devolutas. São Paulo: Secretaria de Estado da Cultura, 1990. p. 44.
} 
concederem muitas datas e ao pobre, que as necessita, nem às vezes pode escrever seus sentimentos. ${ }^{25}$

Infelizmente, no processo em questão não consta a decisão final. Porém, é necessário ressaltar que Salvador Gomes de Oliveira é o patriarca de uma família detentora de poder econômico e político da região estudada. $^{26}$

A forma de ocupação territorial da região, durante o período colonial, resultou em uma estrutura fundiária marcada pela pequena propriedade voltada principalmente para a produção de alimentos. Eduardo Paulon Girardi destaca que, "no Brasil, historicamente, a agricultura camponesa desempenhou papel crucial para o desenvolvimento das grandes culturas de exportação e das atividades mineradoras, pois garantia a produção de alimentos para o abastecimento interno." 27 O papel desempenhado pela província catarinense durante o período colonial era o de produtor de alimentos, já que "Santa Catarina supria o mercado interno principalmente com a produção de farinha de mandioca, atendendo, além do mercado local, outras regiões do país e do Cone Sul (Uruguai e Argentina)."28

A análise da produção econômica não se constitui em objeto específico deste trabalho, porém, não pode ser desprezada a relação entre estrutura fundiária e atividade econômica desenvolvida. A região da baía da Babitonga, desde o início de sua ocupação, se caracterizou como de fronteira agrícola aberta, cujo processo de expansão expulsou, e dizimou, as populações indígenas ou "bugres" (como denominados pelos governantes e pela população local). Foi, também, um porto responsável pelo afluxo de escravos africanos e importação e exportação de alimentos.

Do século XVII até as primeiras décadas dos oitocentos, a terra obtida por intermédio da concessão de sesmarias só era legitimada mediante documento outorgado pelo Governo. De posse da carta de cessão, os sesmeiros intitulavam-se proprietários da terra, e esse entendimento fez

\footnotetext{
${ }^{25}$ Requerimento de terras por Faustino Alves da Rosa, op.cit.

26 Ver: OLIVEIRA, Ricardo Costa. "Homens bons" da Vila de Nossa Senhora da Graça do Rio de São Francisco: uma "elite senhorial" do Brasil Meridional nos séculos XVIII e XIX. Revista do Arquivo Histórico de Joinville, Joinville, v.1, n.1, 2007.

${ }^{27}$ GIRARDI, Eduardo Paulon. Atlas da questão agrária brasileira - 2008. Disponível em: <http://www2.fct.unesp.br/nera/atlas/> Acesso em: 10 set. 2009.

${ }^{28}$ SILVA. A divisão político-administrativa do Estado de Santa Catarina, op.cit., p.39.
} 
surgir a concepção da terra como propriedade privada. Portanto, será o arcabouço jurídico que determinará ser a propriedade pública ou privada.

Carlos Alberto Serra ressalta que o período colonial foi marcado por uma vasta e conflitante legislação sobre a concessão de terras. Porém enfatiza que:

Concomitantemente ao regime de concessão de sesmarias, foi se firmando no Brasil, por imperativos econômicos e sociais, o sistema de posse, circunscrita de início à pequena exploração agrícola, operada por pessoas de poucos recursos, chamadas posseiros. Estes, muitas vezes, tinham suas terras apropriadas por senhores influentes no governo, o que proporcionou a formação de grandes latifúndios, com dezenas de léguas de extensão em terras contínuas, apesar da promulgação da Resolução de 17 de julho de 1822, que aboliu o sistema das sesmarias. ${ }^{29}$

Para Alberto da Silva Jones ${ }^{30}$ a legislação sobre terra contribuiu para o conflito jurídico. Sua análise parte da premissa de que as terras no Brasil são originariamente públicas e que ao longo da história ocorreu um processo de privatização das terras, processo este necessariamente mediado pelo Estado no campo político, jurídico, administrativo, econômico, entre outros. Assumiu características distintas e implicou em situações diversas, conforme os diferentes momentos e conjunturas históricas, econômicas, sociais, políticas e culturais, entre outras igualmente relevantes, vividas ou enfrentadas pelo Brasil, desde suas origens coloniais.

Em relação aos efeitos dessa política colonial, James Holston afirma: "Em 1822, no ano da independência, a instituição das sesmarias já havia produzido uma perversão: depois de três séculos de colonização, o país era uma terra sem povo e um povo sem terra". ${ }^{31}$

${ }^{29}$ SERRA, Considerações acerca da evolução da propriedade da terra rural no Brasil, op.cit., p. 237.

30 JONES, Alberto da Silva. Formação histórica do Direito Agrário no Brasil (2). [2005]. Disponível em: <www.vermelho.org.br > Acesso em: 20 mai. 2007.

31 HOLSTON, James. Legalizando o ilegal: propriedade e usurpação no Brasil. Revista Brasileira de Ciências Sociais, São Paulo, n.21, p. 68-87, fev.1993. Disponível em: <http://www.anpocs.org/portal/index.php?option=com_content\&view=article\&id=216:rbcs21\&catid=69:rbcs\&Itemid=399\#4 >. .Acesso em: 23 jul. 2009. 


\section{A distribuição de terras devolutas e as colônias estrangeiras}

$\mathrm{O}$ acesso à terra, durante todo o período colonial brasileiro, esteve sob a égide da Lei de Sesmarias, que, de maneira geral, a partir das concessões efetuadas no território nacional, gestou uma estrutura fundiária baseada na grande propriedade, com latifúndios improdutivos e grande quantidade de terras desocupadas.

A região sul do Brasil, em seu processo de povoamento, no período colonial e imperial, esteve submetida ao mesmo arcabouço jurídico das demais regiões, bem como produziu, ou reproduziu, as relações de poder econômico, político e social típicas das nacionais. No entanto, destaca-se por ter produzido um regime fundiário caracterizado pelo minifúndio, ou seja, pela pequena propriedade, e com terras desocupadas.

O Estado Imperial, pela Resolução de 17 de julho de 1822, extinguiu o regime de sesmarias; já em sua provisão de 22 de outubro de 1823, reafirmou a proibição de novas concessões de sesmaria, atribuindo à Assembleia Geral Constituinte a tarefa de regulamentar a matéria.

No entanto, a Constituição Imperial de 1824 ateve-se a proteger o direito de propriedade, ao dispor, no Art.179: "A inviolabilidade dos Direitos Civis, e Políticos dos Cidadãos Brasileiros, que tem por base a liberdade, a segurança individual, e a propriedade, é garantida pela Constituição do Império, pela maneira seguinte,

\section{$[\ldots]$}

XXII. É garantido o Direito de Propriedade em toda a sua plenitude. Se o bem público legalmente verificado exigir o uso, e emprego da Propriedade do Cidadão, será ele previamente indenizado do valor dela. A Lei marcará os casos, em que terá lugar esta única exceção, e dará as regras para se determinar a indenização. ${ }^{32}$

Como não se providenciou, após o fim da Lei de Sesmarias, em 1822, a elaboração de legislação específica para regulamentar a questão

32 REPÚBLICA FEDERATIVA DO BRASIL. Constituição de 1824. Disponível em: <:http://www.planalto.gov.br/ccivil_03/Constituicao/Constitui\%C3\%A7ao24.htm>. Acesso em: 25 out. 2010 . 
fundiária, produziu-se um vácuo jurídico que somente foi preenchido com a Lei de Terras de 1850.

O debate parlamentar ocorrido durante a elaboração da Lei de Terras foi analisado por Claudia Christina Machado e Silva, ${ }^{33}$ que demonstra as contradições e oposições que permearam todo o processo sobre a regularização da propriedade até, finalmente, se chegar à promulgação da lei que regulamentou a venda de terras devolutas. A percepção de que eram terras desocupadas desconsiderou a realidade da presença de pessoas que dela tiravam seu sustento.

De maneira sintética, reproduzo as formas elencadas por Marés ${ }^{34}$ relativas à situação das terras no Brasil antes da Lei de Terras de 1850:

a) sesmarias concedidas antes de 1822 e integralmente confirmadas, portanto, reconhecidas pela Constituição como propriedade privada e protegidas legalmente;

b) sesmarias concedidas antes de 1822 mas não confirmadas por falta de ocupação, demarcação ou produção;

c) glebas ocupadas por simples posse, para viver e produzir;

d) terras ocupadas para algum uso da Coroa ou do governo local, como praças, estradas, escolas, prédios públicos, consideradas de domínio público;

e) terras sem ocupação (todas as que não se enquadrassem nas categorias anteriores eram consideradas sem ocupação, mesmo que alguém ali estivesse e dela tirasse seu sustento e vida).

Para Ruy Cirne Lima,

Apoderar-se de terras devolutas e cultivá-las tornou-se cousa corrente entre os nossos colonizadores, e tais proporções essa prática atingiu que pôde, com correr dos anos, vir a ser considerada como modo legítimo de aquisição do domínio, paralelamente a princípio, e,

33 SILVA, Claudia Christina Machado e. Escravidão e Grande Lavoura: o debate parlamentar sobre a Lei de Terras (1842-1854). Curitiba, 2006. 137f. Dissertação de Mestrado (História). UFPA. Disponível em: <http://dspace.c3sl.ufpr.br/dspace/handle/1884/6666> Acesso em: 20 mai. 2009.

${ }^{34}$ MARÉS. A função social da terra, op.cit., p. 68. 
após, em substituição ao nosso tão desvirtuado regime das sesmarias ${ }^{35}$.

Na província de Santa Catarina, durante o período de proibição de distribuição de terras devolutas, os governantes, com a autorização da Assembleia Legislativa, incentivaram a colonização em terras devolutas por nacionais ou estrangeiros. A fala do presidente Feliciano Nunes Ribeiro, em $1^{\circ}$. de março de 1835 , perante a Assembleia Legislativa de Santa Catarina, é ilustrativa:

[...] com o arbítrio que tendei a facilitar o aproveitamento de terras devolutas onde as houvesse tais e sem oposição, ficando os aproveitadores sujeitos ao que a respeito de concessão e distribuição de terras haja de ser competentemente determinado; $[\ldots]^{36}$

Afirmava ainda o governante que, apesar da notável possibilidade oferecida para o aproveitamento de terrenos devolutos, com todas as vantagens que eles prometiam, poucos moradores tinham se apresentado, e entendia serem dois os principais motivos para tal comportamento: o medo dos "bugres" e a falta de meios para principiar novos estabelecimentos. Para o presidente, a colonização promovida pelo Estado deveria privilegiar a população local e dessa forma contribuir para a expansão da fronteira agrícola.

Diante da precariedade da condição vivida por muitos dos homens livres pobres, que se viam impedidos de se tornarem lavradores de suas próprias terras mediante o instituto legal, a carta de cessão, outros tantos continuavam a ocupar terras locais, já que a fiscalização não se fazia tão visível ou era tolerada pelas autoridades locais.

Em 1840, o presidente da província, marechal de campo Francisco Jozé de Souza Soares d'Andrea, em seu discurso à Assembleia Legislativa, referindo-se à colonização, discorreu sobre a importância da existência de terras medidas e demarcadas. Segundo ele, tais terras deveriam ser dadas aos colonos que se apresentassem, e até mesmo aos "filhos da Província",

\footnotetext{
${ }^{35}$ LIMA. Pequena história territorial do Brasil, op.cit., p.51.

${ }^{36}$ RIBEIRO, Feliciano Nunes. Discurso à Assembleia, em 01 de março de 1835. Cidade do Desterro. Disponível em: <http://crl.edu/content/brazil/scat.htm>. Acesso em: 05 set. 2010.
} 
desde que tivessem determinada idade, fossem casados e sem escravos, e "nem outros meios que os seus braços, e a sua robustez". 37

No município de São Francisco do Sul, após a independência do Brasil, mais precisamente na década de 1840 , dois fatos relacionados à ocupação territorial mobilizaram as autoridades provinciais e integrantes da elite local.

Um deles, o contrato celebrado entre o governo imperial e o empresário Benoit Joseph Mure, em 1841, para a criação de uma colônia industrial, na Península do Saí, e para a qual foram concedidas duas léguas quadradas de terras devolutas. O referido contrato previa a instalação de aproximadamente 500 franceses. A singularidade da colônia residia no fato de que estaria assentada nas premissas do pensamento de Charles Fourier, socialista utópico. ${ }^{38}$

Para decepção dos governantes e das elites locais, que anteviam o progresso econômico da região e concomitantemente a valorização de suas propriedades, o projeto fracassou em decorrência das dificuldades do território e também pelas qualificações e expectativas dos colonos franceses.

A respeito da colônia, assim se pronunciou o presidente da província, em 1851:

Essa colônia de que tanto se falava antes de chegada dos colonos teve princípio em janeiro de 1842 com o estabelecimento dos primeiros, que logo se desouveram, e não obstante ter chegado mais de 117 no mesmo ano pode-se dizer, que expirou em 1843, pois dos 210 apenas nela existiam no fim do ano 9 indivíduos, sem estabelecimento algum. Isso mais me convence, de que o comunismo não pode achar abrigo entre nós. ${ }^{39}$

\footnotetext{
${ }^{37}$ D'ANDREA, Francisco Jozé de Souza Soares. Discurso à Assembleia Legislativa, em 01 de março de 1840. Cidade do Desterro. Disponível em: <http://crl.edu/content/brazil/scat.htm>. Acesso em: 20 abr. 2009.

38 Ver: S.THIAGO, Raquel. Fourier: uma esperança e utopia na Península do Saí. Blumenau: Ed. da FURB, Florianópolis: UFSC, 1995.

${ }^{39}$ COUTINHO, João José. Fala dirigida à Assembleia Legislativa da mesma província, por ocasião da abertura da sua sessão ordinária em o $1^{\circ}$. de março de 1852 . Cidade do Desterro. Disponível em: 〈http://www.crl.edu/content/brazil/scat.htm〉. Acesso em: 20 abr. 2009.
} 
O segundo episódio a ser colocado em destaque sobre a existência de terras legais e ilegais, ou não legitimadas, na região, foi o casamento da princesa Dona Francisca, irmã de D. Pedro II, com o Príncipe de Joinville. A Lei n.166 de 20 de setembro de 1840 estabelecia o dote das princesas brasileiras e em seu Art. 4 determinava a fundação de um patrimônio em terras pertencentes à Nação, e incluía no dote da princesa, no $\S 3^{\circ}$., 25 léguas quadradas, de três mil braças, de terras devolutas, que podiam ser escolhidas na melhores localidades em um, ou mais lugares, na Província de Santa Catarina. ${ }^{40}$

O presidente da província, para cumprir a determinação do Governo Imperial, informou ao Legislativo Provincial, em 1845, que havia recebido o representante do Príncipe de Joinville e esclarecido todos os detalhes solicitados e principalmente que:

[...] lhe indiquei em São Francisco as melhores terras que há na Província, e que devem agradar sua Alteza, por abrangerem em contiguidade as 25 léguas quadradas que the foram concedidas. São terras devolutas, ricas em madeiras, e segundo opiniões, também de minerais. Quanto à sua posição, acham-se estendidas ao longo da projetada linha de defesa contra os bugres, e era onde eu intencionava formar colônia de nacionais. $^{41}$

E se mostrava esperançoso:

Se, com efeito, forem povoadas, sairá o Distrito de São Francisco do letargo em que se acha por falta de braços, e poderá em breve vir a ser o primeiro da Província, onde há o melhor porto para grandes navios, sendo que na proximidade das terras, de que falo, podem ter as futuras colônias vários outros portos. ${ }^{42}$

40 FICKER, Carlos. História de Joinville: crônica da colônia Dona Francisca. 3.ed. Joinville: Letradágua, 2008. p.24.

${ }^{41}$ BRITO, Antero Jozé Ferreira de. Discurso à Assembleia, em 01 de março de 1845. Cidade do Desterro. Disponível em: 〈http://crl.edu/content/brazil/scat.htm〉. Acesso em: 01 nov. 2010.

${ }^{42}$ Ibidem. 
Em importante publicação para a compreensão da história da região da baía da Babitonga, Carlos Ficker ${ }^{43}$ fornece indícios das características da ocupação da região. Em uma correspondência datada de 29 de novembro de 1844, endereçada ao ministro do Império José Carlos Pereira de Almeida Torres, o Príncipe de Joinville, por meio de seu procurador, o conselheiro Barbosa da Silva, reclamava a entrega das terras dotais. Informava que, diante de seu desconhecimento da região, havia designado o vice-cônsul da França em Santa Catarina, Léonce Aubé, para a tarefa da escolha do local para a demarcação dos terrenos:

Segundo me informa Monsieur Aubé, o litoral está invadido legítima e ilegitimamente, assim como as margens dos rios navegáveis de um e outro lado; sendo assim, e conhecendo-se que as terras decrescem de preços e melhoria à medida que se afastam do litoral e dos meios naturais de comunicação que facilitam a exportação dos gêneros que possam produzir, segue-se que não havendo terras no litoral, não se pode preencher literalmente o contrato sem que se entre na indagação da legitimidade ou ilegitimidade dos que as habitam, porque nesse caso me parece que, excluídos os intrusos e posseiros das margens dos rios, sobrarão terras a preencher a data concedida em todas as suas condições. $^{44}$

Portanto, evidencia-se a existência de terras ocupadas mediante a simples posse, estratégia utilizada pelos pequenos lavradores nacionais para proverem sua subsistência. É possível, também, vislumbrar no texto a concepção de que terras não ocupadas legitimamente se constituírem em terras devolutas.

Segundo as informações que vocalmente me deu o Snr. Léonce Aubé, soam de pouca monta as benfeitorias que existem na margem direita do rio São Francisco,

\footnotetext{
${ }^{43}$ Carlos Ficker, brasileiro, cronista, historiógrafo, utilizou jornais e fontes documentais na elaboração de suas publicações relativas à imigração e colonização europeia em Santa Catarina. Após seu falecimento (1974), o município de Joinville adquiriu seu acervo particular, que se encontra no Arquivo Histórico de Joinville, composto de mais de 20 mil documentos, livros contábeis da Colônia Dona Francisca, mapas, fotografias, livros e registros variados.
}

${ }^{44}$ FICKER. História de Joinville, op.cit., p. 28. 
excetuada a Fazenda das Três Barras, que vai designada na carta e que pode ficar de fora, que talvez valha a pena indenizar os proprietários ou invasores delas, e fazer-se ali a concessão, pois à exceção do litoral, o mais está devoluto. ${ }^{45}$

O procurador alertava que o Príncipe de Joinville pretendia que as 25 léguas quadradas de terras fossem em uma área única e que não desejava violência a "cidadãos brasileiros". Por este motivo, entendia ser preferível "a indenização das benfeitorias e o consentimento de continuarem os que estão a cultivar as terras que se lhe marcarem, mediante um reconhecimento de senhorio, desvia toda a ideia de coação." 46

A existência de terras ocupadas por meio de posse foi reconhecida indiretamente pelo presidente da província em oficio enviado ao juiz municipal e delegado do Termo de São Francisco, em 1845, onde apresentava o conselheiro e tenente coronel de engenharia Jerônimo Francisco Coelho como o responsável pela tarefa de proceder à medição e demarcação das terras dotais, afirmando que ficara definido realizar desvios "desviando-se unicamente quando for indispensável para salvar pelos fundos as terras apropriadas, apossadas ou cultivadas, que existem nas margens do mesmo rio (São Francisco) e seus confluentes". ${ }^{47}$

Desse modo, as próprias autoridades reconheciam a existência de ocupações que não estavam assentadas de acordo com a legislação vigente.

Para James Holston a recorrente prática da ilegalidade das ocupações no Brasil tem suas raízes fincadas na colonização promovida pela Coroa Portuguesa, e ao longo de seu trabalho o autor argumenta que,

Dadas as dimensões continentais do país e as vastas faixas de terra não cultivadas e em disputa no interior das áreas reservadas às plantações, as invasões eram uma alternativa sempre presente, tolerada, e até ignorada - a não ser quando alguém conseguia uma concessão que incluía a terra invadida. As posses, assim, tornavam possível a condição de colonos livres àqueles que não podiam participar da economia

\footnotetext{
${ }^{45}$ FICKER. História de Joinville, op.cit.

${ }^{46}$ Ibidem, p.29.

${ }^{47}$ BRITO. Discurso à Assembleia, em 01 de março de 1845, op.cit.
} 
comercial, e ainda serviam de trunfo para os imigrantes mais pobres - os habitantes das fronteiras, os meeiros e os pequenos agricultores - contra o regime dos latifundiários. $^{48}$

Convém ressaltar que, no processo de escolha e posse das terras dotais, o Príncipe de Joinville manifestou o desejo que, diante da constatação da legitimidade, ou de cultivo das terras, se procedesse à indenização das benfeitorias ou ao consentimento na permanência após a demarcação dos terrenos ocupados. ${ }^{49}$

Alguns governantes percebiam a precária situação dos lavradores nacionais, principalmente frente aos estrangeiros. O presidente Antero Jozé Ferreira de Brito, em 1844, afirmou, perante a Assembleia Legislativa, que pleiteava que aos nacionais fossem estendidas as condições e benefícios concedidos aos estrangeiros para o acesso à terra. Em seu entendimento:

[...] mas não é menos certo, que esse miseráveis de quem tenho falado, não dispondo de um real para comprarem ferramentas e para se alimentarem enquanto não o podem fazer com o fruto de seu trabalho, se não atrevem a pretendê-las. ${ }^{50}$

E prossegue sugerindo "que os nacionais, nas circunstâncias indicadas, sejam colonizados; que se lhes forneça os instrumentos aratórios indispensáveis, e por tempo de um ano algum socorro pecuniário para se alimentarem".

Dentre os relatórios dos presidentes da província, principalmente aqueles elaborados no período que precedeu a promulgação da Lei de Terras de 1850, destaca-se o do presidente Antero de Brito. Ao se referir, em 1848, à Lei n.514, que concedeu a cada uma das Províncias do Império seis léguas de terras devolutas, destinadas exclusivamente à colonização, o que na prática significou a proibição de concessão de terras aos nacionais, ele foi categórico:

\footnotetext{
${ }^{48}$ HOLSTON. Legalizando o ilegal, op.cit.

${ }^{49}$ FICKER, História de Joinville, op.cit., p. 29.

${ }^{50}$ BRITO, Antero Jozé Ferreira de. Discurso à Assembleia, em 01 de março de 1844, Cidade do Desterro. Disponível em: <http://crl.edu/content/brazil/scat.htm>. Acesso em: 20 abr. 2009.

${ }^{51}$ Ibidem.
} 
[...] a distribuição de terras é um elemento de ordem, a não distribuição legal é, ao contrário, de desordem: a distribuição e cultura desse imenso sertão devoluto tem sido de uma vantagem para esta Província, tem dado lugar a muitos casamentos e a formarem-se novos estabelecimentos ocupando braços que estariam ociosos, e disponíveis a atentados. [...] com a dita medida muitas desordens se tem evitado, pois que em vez de cada um usar por esses sertões do direito da força para se apossar de terras disputadas por outro que delas se apossou com o mesmo direito, recorria à presidência pedindo, e the eram concedidas terras inteiramente desembaraçadas e devolutas, de agora em diante estou certo que uns aos outros acometerão, e invadirão, e conte-se com a grande luta, e muitos atentados, e impossíveis de evitar nesses sertões onde não pode chegar a ação da autoridade. Eu lembro a conveniência de se fazer conhecer ao Governo Imperial o perigo da proibição das concessões. ${ }^{52}$

Com a aprovação da Lei Imperial n. 601, de 1850, os governantes provinciais deveriam suspender a concessão de terras devolutas, já que a legislação preconizava que o acesso a elas somente se faria mediante a compra. Para Marés, o governo brasileiro, ao adotar a visão economicista como forma de qualquer um tornar-se proprietário, na prática impediu o acesso dos pobres às terras. Afinal, "Não se pode esquecer que a compra é um contrato bilateral, e o vendedor vende o quê e quando quer. Isto quer dizer que foi retirado qualquer direito aos cidadãos de reivindicar, mesmo por compra, terras devolutas"

Para Cristiano Christillino, a dificuldade de revalidação dos títulos e legitimação de posses exigida pela Lei de Terras deve ser entendida a partir da seguinte perspectiva:

[...] uma vez passando pelas mãos dos presidentes provinciais, poderiam ser flexibilizadas de modo a privilegiarem os interesses dos seus requerentes. A regulamentação da Lei de Terras mostra que a sua

52 BRITO, Antero Jozé Ferreira. Discurso à Assembleia, em 01 de março 1848, Cidade do Desterro. Disponível em: <http://crl.edu/content/brazil/scat.htm>. Acesso em: 20 abr. 2009.

${ }^{53}$ MARÉS. A função social da terra, op.cit., p.71. 
aplicação foi redirecionada pra não impor os processos de legitimação e revalidação aos fazendeiros, porque isso questionaria o seu direito de propriedade. ${ }^{54}$

Ao mesmo tempo, a Lei de 1850 permitia que, após a medição e demarcação, as terras devolutas fossem disponibilizadas, através de venda, para empresas particulares, visando à criação de núcleos coloniais estrangeiros ou nacionais.

A colonização estrangeira é temática recorrente nas falas e relatórios dos presidentes da Província de Santa Catarina, tanto no sentido de se acelerar o povoamento da província como, e principalmente, na expectativa de que através do estabelecimento de imigrantes europeus ocorresse a inserção de novas técnicas produtivas que propiciassem um avanço na atividade agrícola, resultando em progresso na economia provincial. ${ }^{55}$

Uma recente e significativa publicação de Márcio Antonio Both da Silva, sobre história regional, mais especificamente sobre a história da região de matas do Rio Grande do Sul, contém discussões que têm inúmeras correlações com as especificidades do povoamento da região da baía da Babitonga. Logo no prefácio, um alerta de Paulo Zarth, em relação ao processo de colonização e ao consequente progresso advindo da ocupação territorial por colonos europeus,

[...] o progresso é branco e europeu. O atraso poderia ser revertido através de um processo de conversão, pela transformação de índios e nacionais em colonos fixos, residentes, produtivos, civilizados e ordeiros. Tal transformação viria pela comparação, pelo exemplo dos colonos, e sobretudo forçando-os a se confinarem em lotes de terras delimitados nos padrões impostos pelo

54 CHRISTILlinO, Cristiano Luís. Litígios ao sul do Império: a Lei de Terras e a consolidação política da Coroa no Rio Grande do Sul (1850-1880). Niterói, 2010. 350 f. Tese. Instituto de Ciências Humanas e Filosofia, Departamento de História. Universidade Federal Fluminense - UFF. p.14.

${ }^{55}$ Ver: CAVALCANTI, José Mariano de Albuquerque. Discurso à Assembleia em 5 de abril de 1836. Cidade do Desterro. Disponível em: < <http://crl.edu/content/brazil/scat.htm> . Acesso em: 20 abr. 2009; COUTINHO, João José. Discurso à Assembleia em $1^{\circ}$. de março de 1853. Cidade do Desterro. Disponível em: 〈http://crl.edu/content/brazil/scat.htm〉. Acesso em: 20 abr.2009. 
Estado e pelas companhias de colonização”. (grifo do autor). ${ }^{56}$

Como indicado anteriormente, na década de 1840 os governantes e a elite local viram frustradas suas expectativas em relação às colônias estrangeiras com o fracasso da colônia do Saí. No entanto, antes da promulgação da Lei de Terras, o governo imperial aprovou, através do Decreto $\mathrm{n}^{\circ}$. 537, de 15 de maio de 1850, o contrato celebrado com a Sociedade Colonizadora para a fundação de uma colônia agrícola em terras pertencentes ao dote da princesa Dona Francisca. Pelo contrato, ficou estabelecido que o Príncipe de Joinville e a princesa concederiam oito léguas quadradas à Sociedade Colonizadora. ${ }^{57}$

A região, que, nas palavras do presidente da província de 1845 , poderia ter recebido uma colônia nacional, viu surgir a Colônia Dona Francisca, em 1851, com a chegada dos primeiros colonos europeus. As expectativas do governante, em $1845,{ }^{58}$ eram de que as terras dotais pudessem imprimir significativo aumento da ocupação e do progresso econômico da região. Como em 1866 a Colônia Dona Francisca originou o município de Joinville, se pode considerar que tais expectativas estavam parcialmente se concretizando.

Afinal, como destaca Carlos H. Oberacker, ${ }^{59}$ o propósito inicial do governo com as colônias não se restringia a importar braços para a lavoura, mas contemplava outros objetivos: demográficos (povoamento), morais (dignificação do trabalho manual), sociais (formação de uma camada média), militares (defesa das fronteiras) e, naturalmente, econômicas (abastecimento das cidades e do exército).

\footnotetext{
${ }^{56}$ ZARTH, Paulo A. Prefácio. In: SILVA, Márcio Antonio Both da. Babel do Novo Mundo: povoamento e vida rural na região de matas do Rio Grande do Sul (1889-1925). Guarapuava: Unicentro, 2011; Niterói, UFF, 2011.

${ }^{57}$ FICKER. História de Joinville, op.cit., p.54.

58 BRITO. Discurso à Assembleia, em 01 de março de 1845, op.cit.

59 OBERACKER Jr., Carlos H. A colonização baseada no regime da pequena propriedade agrícola In: HOLANDA, Sérgio Buarque de (dir.). História geral da civilização brasileira tomo II, O Brasil Monárquico, Reações e Transações, 3º. volume. São Paulo: Difel, 1985. p.223.
} 


\section{Considerações gerais}

O povoamento da região nordeste de Santa Catarina tem características muito semelhantes ao processo de ocupação do território nacional, ou seja, a concessão de sesmarias, posse e distribuição de terras devolutas. Durante o período colonial, os pedidos de concessão de sesmaria ou de posse de alguma data de terra, mas sem título de legitimação, feitos por pessoas sem nenhuma propriedade, eram atendidos pelos governantes com muita regularidade.

No período imperial, a sistemática de ocupação de terras após a proibição de concessão de sesmarias privilegiou a distribuição de terras devolutas, que no entender dos governantes provinciais se constituía em excelente instrumento de pacificação da província.

Nesta perspectiva, o fato de algumas autoridades expressarem preocupação com a situação dos lavradores pobres, geralmente os nacionais, não pode ser considerado como uma atitude de confronto com as determinações do governo imperial, apenas desnuda a realidade vivida pela maior parte da população.

Para os homens pobres livres a ocupação de um pedaço de terra, fonte de sobrevivência da família, oriunda de posse legítima ou não, foi um dos recursos utilizados no início do processo de povoamento da região. Porém, quando a legislação fundiária criou efetivamente a figura da propriedade privada, esses atores sociais perceberam a importância de serem reconhecidos como proprietários de terras legitimados pelo instituto legal. A posse, por si só, já não legitimava mais o domínio da terra. 